\title{
030 \\ Impacts of climate change on forests in different climatic zones and their implications on sustainable development
}

\author{
W A J M De Costa \\ Department of Crop Science, University of Peradeniya, Sri Lanka.
}

\begin{abstract}
Atmospheric and meteorological data collected during the last few decades show clear evidence that global climate is undergoing a long-term change. Increasing atmospheric concentrations of greenhouse gases (i.e. $\mathrm{CO}, \mathrm{CH}_{4}, \mathrm{NO}$ and $\mathrm{CFCs}$ ) and the consequent warming of the atmosphere are clear features of long-term climate change. Because of their long life span, these changes in climate are likely to influence the functioning and productivity of forest ecosystems. The objective of this review is to predict the impacts of climate change on forests on the basis of experimental results on key plant physiological and ecological processes.
\end{abstract}

There is clear experimental evidence that increasing atmospheric $\mathrm{CO}_{2}\left(\mathrm{C}_{2}\right)$ increases photosynthesis and biomass production of forests. However, the magnitude of growth stimulation is likely to vary with temperature. The highest increases in productivity are expected to occur in the cooler and moist climatic zones while the productivity increases would be lowest or absent in the warmer and drier zones. It is highly probable that the species composition of forests in all climatic zones would change because of the differential response of different plants species to increases in $\mathrm{C}_{\mathrm{a}}$ and temperature. There is clear evidence that the underlying physiology of all plant species become relatively drought tolerant with increasing $\mathrm{C}$. Hence, there is a possibility that in areas which are not deforested due to human population pressure, the existing forests would spread beyond their present boundaries with lowland evergreen forests extending to relatively drier, sub-humid climates and dryland deciduous forests extending to relatively semi-arid climates.

Climate change induced changes in forests will definitely trigger changes in soil and in the complex network of organisms that inhabit forests. While the inputs of carbon and nutrients to the soil through litter fall and root exudates are likely to increase with increasing $\mathrm{C}_{\mathrm{a}}$, soil organic matter decomposition would also increase with increasing soil temperatures. Photosynthesis in a future high $\mathrm{CO}_{2}$ environment will produce plant tissues with higher carbohydrates, but lower nitrogen. This will affect the populations of organisms which feed on plants. Therefore, the climate change induced changes in forests could cause wide ranging and complex secondary and tertiary effects on the whole forest ecosystem.

It is well-established that management of forest resources is a vital component of sustainable development. Therefore, understanding and identifying the impacts of climate change on forest ecosystems would be essential in formulating rational forest management strategies to achieve longterm sustainable development.

\section{1 \\ Measures for a sustainable lobster fishery \\ D N Koralagama, O Amarasinghe and D S Jayakody University of Ruhuna, Sri Lanka}

Lobsters, the crustaceans have four varieties as spiny, slipper, clawed and coral reef lobsters. Although all the species have a biological and environmental importance only two varieties; spiny and slipper lobsters have acquired the market and attribute for the fishery. Lobster fishery is a paramount component which contributes more than five percent foreign exchange from total fish earnings in Sri Lanka. This has an export oriented market with attractive high prices, around $2000 \mathrm{LKRkg}^{-1}$. The fishery has explained as a capture fishery. Therefore, the resource is subjected to over exploitation due to unattainable demand. That means, the fishery is currently in a period of transition era of open access to a period of limited access. In fact, it needs a well managed, monitoring plan and functioning rules and regulations towards a sustainable lobster fishery that would be discussed through this study.

The data were collected from five lobster processing companies and three purchasing centers in Gampaha district. Informal discussions were held with officers at NARA and ministry of fisheries. The sustainability was calculated using surplus yield model (Schaefer, $1954-1957$ ).

Proceedings of the International Forestry and Environment Symposium 2006 of the

Department of Forestry and Environmental Science. University of Sri Jayewardenepura, Sri Lanka 
During 1980 s to early 1990 s, the only lobster variety exported was spiny lobsters: but with the absence of enough spiny lobster stock, marketers and buyers tend to demand slipper lobster also. Therefore, the catch also declined up to mid 1990s and slightly increased in a decreasing manner where the catch drop from $375 \mathrm{mt}$ in 1996 to $247 \mathrm{mt}$ in 2004 with slight variation during the period. So as the Catch Per Unit Effort (CPUE) also decreased from 0.33 percent to 0.09 percent during the period of 1986 1998. The decreasing is mainly due to the over exploitation. Therefore, new remedies, rules and regulations should be implemented.

Habitat enhancement, minimize near shore pollution, usage of appropriate gears, conduct larval settlement and lobster fattening programmes, and facilitate training, extension work cum awareness programmes are some suggestions that could be implemented. Also the primary regulations on lobster fishery should be implemented with restrictions on the fishing efforts (traps) and a quota system. The calculated yield levels permit to harvest only within the range of $359 \mathrm{mt}-388 \mathrm{mt}$ annually.

\title{
$\underline{032}$ \\ Sustainable management of land resources

\author{
A P Pandey \\ Department of Economics, Banaras Hindu University, Varanasi, India
}

Since the dawn of civilization, land and water have been the basic elements of the life support system on our planet. The civilizations flourished well where these natural resources were available in plenty and they declined or perished with their depletion. Civilizations, therefore, learned to respect these resources and found the best ways of using them. In recent times the land resources have been subjected to a variety of pressures. Despite this is surviving and sustaining mankind. What is alarming is the way we use land - our tendency to over-exploit it for a number of reasons, which has led to this pristine resource being robbed of its legendry resilience. Man is the main culprit for degradation of our natural resources like land and water as he views these in terms of their utility and capability to meet his immediate needs and wants. Preserving, protecting and defending land resources have been part of our age- old culture. There are in numerable examples of the traditional practices and systems of conservation, which still survive and are effective. But, with the advent of new forces of consumerism, a predominaritly materialistic value system, short-term profit-driven motives and the greed of the users, the tradition of conservation is detoriating. As a result land has degraded, soil fertility depleted, the rivers polluted and the forests destroyed. The ultimate sufferer is the common man, especially in the third world countries. On the global scale, degradation is equally striking. The world's population has doubled in the last forty years and is now more than five billion at this rate it will cross ten billion in the coming fifty years. The current growth rate of the global economy is a mere 3 percent. Even if this rate expands five times over there will be a critical demand for food, energy, and services.

Keeping in view the scope of degraded and salt affected lands in food security of India and numerous socio economic benefits, it is worth while to examine the pattern, practices policies implications relating to rehabilitation of these problematic lands. The main concern of this paper is to review the reclamation trend of salt affected land, technology available for reclamation economic feasibility and socio-economic benefit and socio-economy and policy constraints in reclaiming these lands.

\section{3}

\section{Towards systematic compilation of environmental information: Review of sources of data on environment with special reference to Land Resource}

\author{
HC Perera \\ Department of Forestry and Environmental Science, University of Sri Jayewardenepura, Sri Lănka.
}

Lack of reliable and up-to-date information on environment limits the effective policy and management decisions on natural resources sector. Eventhough the organizations responsible for supplying environmental information are well established, there is no effective mechanism to provide professional service in dissemination and maintenance of systematic date bases on regular basis. The level of accuracy of data isalways variable and most collected data and information are stored in paperarchives lacking integration within the sub sector. The objective of this sudy was to review the sources available

Proceedings of the Internationa! Forestry and Environment Symposium 2006 of the

Department of Forestry and Environmental Science, University of Sri Jayewardenepura. Sri Lanka 